\title{
The Federal Reserve Reaction Function: Does Debt Growth Influence Monetary Policy?
}

\author{
Richard G. Sheehan
}

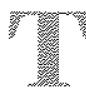
ing $\$ 907$ billion between 1985 and 1990 has renewed doubts about the Federal Reserve's ability to conduct independent monetary policy. Often implicitly underlying these doubts is the fear that increases in federal debt will drive up interest rates and slow economic growth in the absence of expansionary monetary pol. icy. Given the magnitude of projected fedenal deficits, many analysts are concerned that the Federal Reserve may feel obliged to increase the money stock faster than it otherwise would to keep interest rates from rising."

It is the purpose of this paper to offer some evidence on the extent to which the Federal Reserve has at tered monetary policy in response to federal deficits. ${ }^{2}$ The focus here is to determine if monetary policy has reacted to federal deficits in a consistent manner over time. The sensitivity of monetary actions to debt growth is considered over different time periods and

Richard $\mathrm{G}$. Sheehan is an economist at the Federal Reserve Bank of St. Louis. Larry J. DiMariano provided research assistance.

Sargent and Wallace (1981) have gone so far as to argue that the Federal Reserve has only a choice between increasing the money stock sooner or later. While Darby (1984) has disputed this contention, the issue apparently remains unresolved. See Miller and Sargent (1984).

2The process of a debt increase directly leading to expansionary monetary policy is often labeled "monetizing the debt." Given the ambiguities surrounding that phrase, it is not used here. See Thornton (1984) for a detailed explanation of alternate definitions of the phrase. under alternative measures of monetary actions and debt.

\section{MUPM}

The textbook view of the relationship between monetary policy and federal debt can be demonstrated in the context of a simple comparative static money market model, which is summarized in figure 1. Let us assume that money demand (MD) is a function of the interest rate and the level of income and that the Federal Reserve can effectively fix the money supply (MS). With some initial level of income, money demand and supply functions may be represented by $\mathrm{MD}_{\mathrm{o}}$ and $\mathrm{MS}_{\mathrm{w}}$, respectively. Given a structural (or exog. enous or active) change in fiscal policy, say, an expansionary action increasing the deficit income will rise in the short run. ${ }^{3}$ This increase in income, in turn, will lead to an increase in money demand, shifting the money demand curve from $M D_{a}$ to $M D_{1}$ in figure 1 and driving up interest rates. If the Federal Reserve is operating with a monetary aggregate target, monetary policy will not respond to the deficit. The structural

${ }^{3} \mathrm{~A}$ change in fiscal policy, that is, a change in the behavior of fiscal policymakers, is considered structural, exogenous or active. Thus, a fiscal-policy-induced change in the deficit, as one measure of fiscal policy, also is considered exogenous. it is assumed that the fiscal policy change and resulting deficit change are not prompted by a change in the business cycle. A change in the deficit resuiting from a change in, say, real GNP is considered cyclical, endogenous of passive. See Tatom (1984) for a more extensive discussion of the distinction between active and passive deficits. 


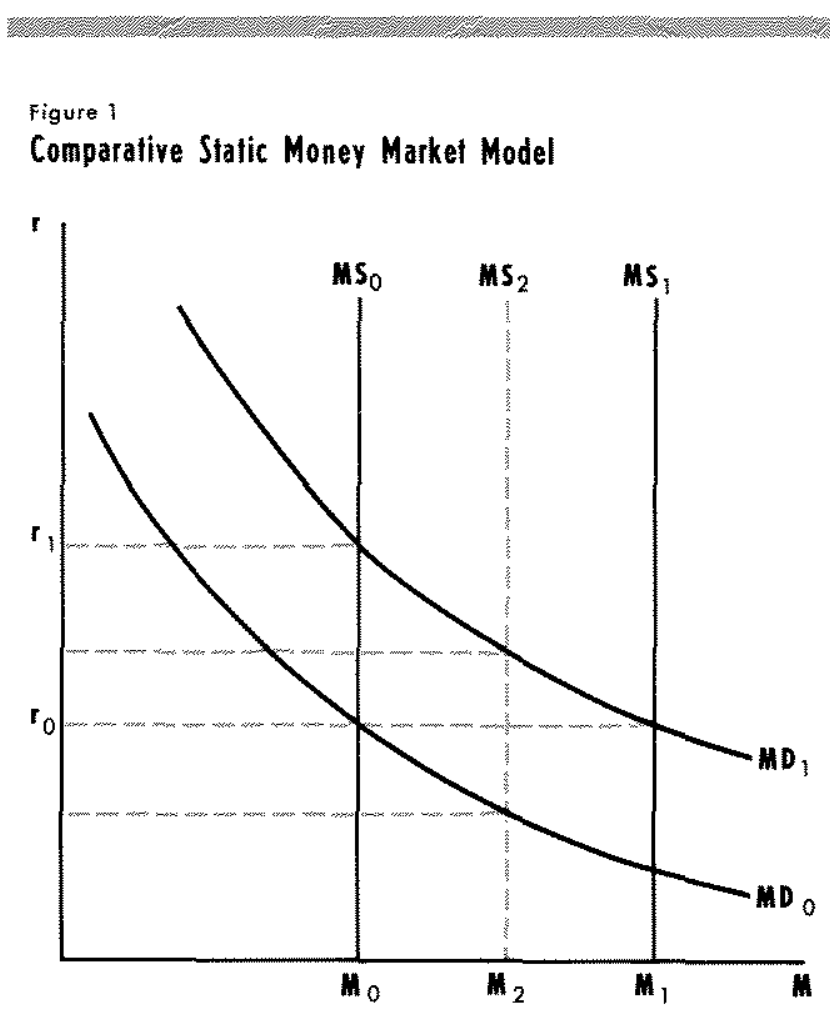

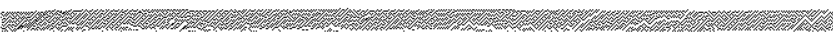

deficit will not alter the money stock but will increase the interest rate from $r_{0}$ to $r_{1}{ }^{+}$

With cyclical (or endogenous or passive) fiscal pol icy changes, however, the impact of changes in the structural deficit is quite different. Assume the economy enters a recession as a result of a non-policy shock to the system. The automatic stabilizing properthes of federal taxes and expenditures will lead to a cyclical increase in the deficit as income declines. Further, the decline in income will reduce the demand for money, shifting the money demand schedule, say, from $\mathrm{MD}_{1}$ to $\mathrm{MD}_{0}$ in figure 1 . Again, if the Federal Reserve is using a monetary aggregate as its target, the money stock will remain constant. An increase in the cyclical deficit will now be accompanied, however, by a reduction in the interest rate from $r_{1}$ to $r_{0,}$. With a monetary aggregate target, this model implies that structural deficits will lead to increases in the in terest rate, while cyclical deficits will be accompanied by decreases in the interest rate.

In contrast, if the Federal Reserve is using the fed

${ }^{4}$ This discussion assumes loanable funds demand is not completely elastic. It further assumes the Federal Reserve is focusing on a monetary aggregate and will not change its desired value of that aggregate in the face of temporary fluctuations in income. eral funds rate as its target, the increase in the structural deficit and the resulting increase in money demand will prompt it to respond differently. The increase in interest rates as money demand increases from $\mathrm{MD}_{0}$ to $\mathrm{MD}_{\mathrm{q}}$ would lead the Federal Reserve to increase the money supply (from $\mathrm{MS}_{3}$ to $\mathrm{MS}_{1}$ ) sufficiently to drive interest rates in general and the federal funds rate in particular back to their original levels. ${ }^{5}$ With an interest rate target, the exogenous deficit increase would not influence the interest rate but would increase the money stock.

If the Federal Reserve has not followed a pure interest rate or monetary aggregate target but instead has followed a mixed strategy using both, a structural deficit would still shift the money demand curve out as before, but the money supply curve would shift out only partially, say, from $\mathrm{MS}_{k,}$ to $\mathrm{MS}_{z}$. "Thus, the structural debt increase would lead to both higher interest rates and higher money growth.

With a federal funds tanget and an increase in the cyclical deficit leading to a decrease in money dem mand from $\mathrm{MD}_{1}$ to $\mathrm{MD}_{\mathrm{s}}$, the Federal Reserve would decrease the money stock from $\mathrm{MS}_{3}$ to $\mathrm{MS}_{\mathrm{t}}$ to keep the interest rate unchanged. With a mixed targeting strategy and an increase in the cyclical deficit, the money supply would be expected to shift partially downward from MS, to MS. Thus, the increased deficit would be accompanied by a lower interest rate and a lower money supply.

Whether an increase in the deficit is accompanied by increases or decreases in the money stock and interest rates depends on the source of the deficit and on the manner in which the Federal Reserve is conducting policy. The alternatives are summarized in table 1.

It should be noted that a given deficit may combine structural and cyclical elements. In that case, the impact of the deficit on the interest rate is ambiguous if the Federal Reserve targets on a monetary aggregate; its impact on the money supply is ambiguous if the Fed targets on interest rates. Both impacts would be ambiguous with a mixed targeting procedure. Further, there is no guarantee that the Federal Reserve has followed (or will follow) a consistent pattern of target-

sf: the Federal Reserve is operating with an interest rate target, it is also necessary to assume that the Federal Reserve believes that money changes can alter interest rates - as they do in this simple model - and that the Fed has a willingness to alter the money stock based on that belief.

Eombra and Moran (1980) cite evidence suggesting this is typical of Federai Reserve behavior. 


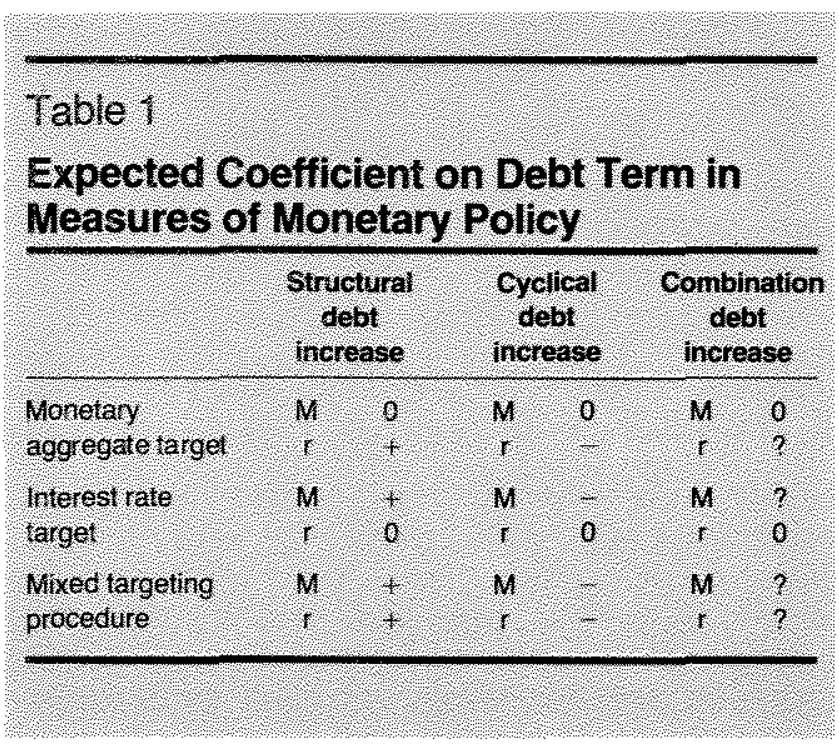

ing on either. Thus, the debt coefficient need not be stable over time.

From 1958 to 1984, the Federal Reserve intermediate policy targets apparently underwent substantial revision. For example, through the $1960 \mathrm{~s}_{f}$ it is generally assumed that the Federal Reserve's primary concern was controlling interest rates. Monetary aggregates began to receive more attention in the early 1970 s. From October 1979 to October 1982, there was an emphasis on monetary aggregate targeting; since then aggregate targeting has become more flexible with less prominence given to M1." Thus, at least four regimes can be identified: (1) from 1958 to approximately 1970 , characterized by interest rate targeting, (2) from the early 1970 s to October 1979, a mixed targeting strategy, (3) from October 1979 to October 1982, a monetary. aggregate target, and (4) from October 1982 to the present, again a mixed targeting strategy. While it would prove truitul to examine "reaction functions" estimated separately over each of these periods, the short time frames of the later two periods preclude that option. Thus, the sample is divided into two subperiods, the first prior to 1971 characterized by interest rate targeting and the second from 1971 with a greater focus on monetary aggregates.

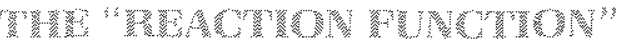

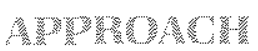

There have been a number of previous studies that have examined the relationship between monetary

\footnotetext{
Tee Lombra and Moran (1980) and Wallich and Keir (1979).

see Thornton (1983) and the sources cited there.
}

policy and federal deficits. Most of these studies fall under the general heading of estimating a "reaction function" for the Federal Reserve. ${ }^{9}$ The reaction function approach assumes that the Federal Reserve's policy actions are based on its goals, its model of the economy and the constraints that the model implies. Thus, the estimated reaction function is based implicitly - or explicitly in the case of McMillin and Beard (1980) - on output and financial market models, together with a rule that is, an assumption about how the Fed will react to disturbances to reach its goals) for determining Federal Reserve behavior. Combining the behavioral assumptions of the policy rule with the output and financial market models predicts how the Federal Reserve will react to disturbances to the economic system - hence, a "reaction function."

Préviously estimated reaction functions have differed with respect to the choice of dependent and independent variables, the functional form employed, the time period used for estimation and the conclusions based on that estimation. They also have reached different conclusions about the stability of the estimated reaction function. Thus, it is useful to briefly survey previously estimated reaction functions.

Three variables commonly have been employed as the dependent variable, that is, as the measure of monetary policy. Niskanen (1978) and Barro (1977) among others use a measure of the money stock, M1, assuming that the money stock is the best indicator of monelary policy during the period of estimation. Froyen (1974), Levy (1981), and Barth, Sickles, and Wiest (1982) use the monetary base instead, contending that the base corresponds more closely to open market operations and is a good measure of exogenous monetary policy actions. The third alternative, used by Abrams, Froyen, and Waud (1980), DeRosa and Stern (1977), and Havrilesky, Sapp, and Schweitzer (1975), is the federal funds rate. They argue that this variable is a more appropriate measure of monetary policy in periods in which the Federal Reserve is targeting on interest rates. They further contend that the Federal Reserve in fact, has targeted interest rates during most of the post-World War II period.

Previously estimated reaction function estimates also have used a wide range of independent variables and have assumed alternate goals of the Federal Re-

\footnotetext{
9For example, see Allen and Smith (1983), Barth, Sickles, and Wiest (1982), Froyen (1974), Hamburger and Zwick (1981, 1982), Levy (1981), McMilin and Beard (1980, 1982). Two studies that do not use the reaction function approach are Dwyer (1982) and Thornton (1984). For a detailed statement of the deficit problem, see Tatom (1984).
} 
serve leg, price stability, low unemployment, high real growth rates and financial market stabilityl. Most previous studies have used ordinary least squares (OLS) estimation techniques, and independent variables generally are included with no more than one lag."

The estimation results have been inconsistent in a number of respects. For example, using the monetary base as the policy measure, Allen and Smith (1983) found that the unemployment rate was significant, while Levy (1981) found it insignificant, On the impact of the debt, included as a measure of financial market stability, Levy concluded that debt growth influenced monetary policy, while Hamburger and Zwick (1981) reached exactly the opposite conclusion. On the stability of the estimated reaction function, Allen and Smith (1983) argued in favor of a stable relationship; Abrams, Froyen, and Waud (1980) reported findings of instability. It is unclear to what extent these differences are due to different sample periods, the choice of independent variables, the specification of the monetary policy variable or the use of different functional forms."

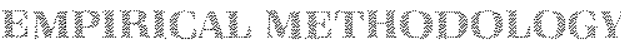

The basic reaction function approach is also employed here. Two alternative monetary policy measures are used as dependent variables: the money stock (M1) and the federal funds rate $\left(i_{\mathrm{F}}\right)$, given that the Federal Reserve has altemately focused on interest rates and the money stock." To further allow comparison of the estimation results with the potential relationships between monetary policy and deficits as presented in table 1, we employ two measures of debt growth in the following empirical analysis: the net federal debt (NFD) and the high employment deficit (HEBD) ${ }^{\text {i: }}$

\footnotetext{
:Levy (1981) used instrumental variables and Abrams, Froyen, and Waud (1980) used 3SLS. Froyen (1974) and studies using Barro's (1977) basic specification used more than one lag.

'See Barth, Sickles, and Wiest (1982) or Mckillin and Beard (1981) for a more extensive review of the reaction function literature.
}

Thonton (1984) uses a different framework focusing on the "causal" relationships between monetary policy and debt rakher than using a reaction function approach. His results are consistent with the findings of the reaction furction literature. There apparenty exists a relationship between monetary policy and federal debt, but this finding is sensitive to the period of analysis chosen as well as the precise measure used for debt.

2The monetary base is not used as a measure of monetary policy since Thornton (1984) has shown the linkage between debt growh and the monetary base is intluenced by a number of other factors.

:Previous reaction functions have generally used either NFD or HEBD although Froyen (1974) used both in the same equation.
Neither of these two measures is a perfect indicalor of the pressure on the Federal Reserve to alter policy in response to changes in federal debt. NFD is potentially influenced by macroeconomic shocks, which may also have an impact on lor be the result of monetary policy. Thus, NFO includes both structural and cyclical components. NFO does have the advantage of including off-budget items, and the recent growth in off-budget items may represent substantial additional pressure on monetary policvmakers. ${ }^{1-4}$ The HEBD measure is adjusted for real income changes. Thus, it may be considered a measure of structural policy changes. HEBD, however, does not include off-budget items.

The equations are estimated over the interval from /1958 to III/1984 (except where noted) as well as over the subperiods from $L / 1958$ to IV/1970 and from $1 / 1971$. to III/1984. The entire period is best characterized in terms of table 1 as a mixed targeting procedure. The early subperiod is basically a time of interest rate targeting, while the latter conforms most closely to a monetary aggregate targeting procedure.

The estimated equations are of the form presented below, a specification similar to that of Froyen (1974):

(1) $X_{1}=\alpha_{i}+\sum_{i=1}^{\sum} \alpha_{i} X_{t-i}+\sum_{j=0}^{J} \beta_{i} Z_{t-i}+\underset{k=0}{\sum} \gamma_{k} D_{t-k}$

where $\mathrm{X} \equiv$ a measure of monetary policy;

$$
\begin{aligned}
& Z=\text { a vector of measures of the goals and con- } \\
& \text { straints of the Federal Reserve; } \\
& \mathrm{D} \equiv \text { a measure of debt; }
\end{aligned}
$$

and $\alpha, \beta$, and $\gamma$ are the estimated parameters.

"The right-hand-side variables include lags of the dependent variables as well as current and lagged values of the stabilization objectives or goals used by the Federal Reserve." Included in the specification are the general price level $(\mathrm{P})$, the unemployment rate (UR), and alternately each of the two measures of federal debt. Following the previous reaction function

\footnotetext{
${ }_{14}^{14}$ ror example, off-budget iferns totaled $\$ 17.3$ biltion in fiscal year 1982

${ }^{15}$ See deleeuw and Holloway (1982).

${ }^{16}$ Froyen has noted that the estimated reaction function actually represents a joint lest of the influence of the chosen stabilization goals and constraints together with the appropriateness of the chosen dependent variable. Lags of the dependent and independent variables are included (1) to allow gradual adjustment to goals so that monetary policy is not a source of instability and (2) to capture the effect on monetary policy of variables omitied from the model.
} 
literature, interest rate terms are included in the money equation, while money tems are included in the interest rate equation.

All variables were included in log difference form except for HEBD, which is included in level form. Maximum lag lengths were arbitrarily nestricted to 12 lags on the dependent variables and six lags for the other night-hand-side variables. The choice of appropriate lag length was then determined by Akiake's final prediction exror (FPE) criterion." When the FPE search for the preferred lag specification indicated that no values of a right-hand-side variable improved the specification, that variable was dropped from the basic equation. Except when noted, a variable was included in the estimated equation only when an F-test on its joint coefficients indicated it was significant at the 10 percent level. Two-stage least squares was used as the estimation technique to avoid problems of simultaneity. ${ }^{18}$

\section{QSE}

The reaction function results estimated over the 1958-84 period are presented in tables 2 and 3 . Tables 4 and 5 include the results of equations estimated from 1958 to 1970 , while tables 6 and 7 present results of equations estimated over the 1971-84 interval. The focus of the following discussion is on the debt variable and the extent to which federal deficits have influenced monetary policy. The debt coefficients are interpreted in light of the predicted coefficient signs from table 1 .

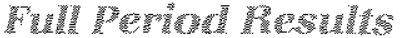

Table 2 presents the equations estimated initially with NFD as an independent variable. The top part of the table presents the coefficient sums and the $t$ statistics on whether that sum is significantly different from zero. At the bottom of table 2 , the significance

\footnotetext{
${ }^{17}$ See Batten and Thornton (1984). In one instance below, the FPE chose the maximum lag length allowed. In that case, the maximum lag length was increased but further lags were insignificant.

${ }_{18}$ Only one equation is estimated, and this pertod 's inflation, unemployment rate, etc. may be influenced by this period's monetary policy. In the first stage, each of the dependent variables was te gressed on 10 lags of itself and four lags of all other variables in the model. The maximum lag lengths were arbitrarily restricted. The second stage, reported in the text, replaces the current values of the independent variabies with the first stage estimates. If HEBD were an exogenous policy toot, the use of an instrument for HEBD would be unnecessary. There is no reason, however, to assume that current fiscal policy is independent of, say, current monetary policy actions.
}

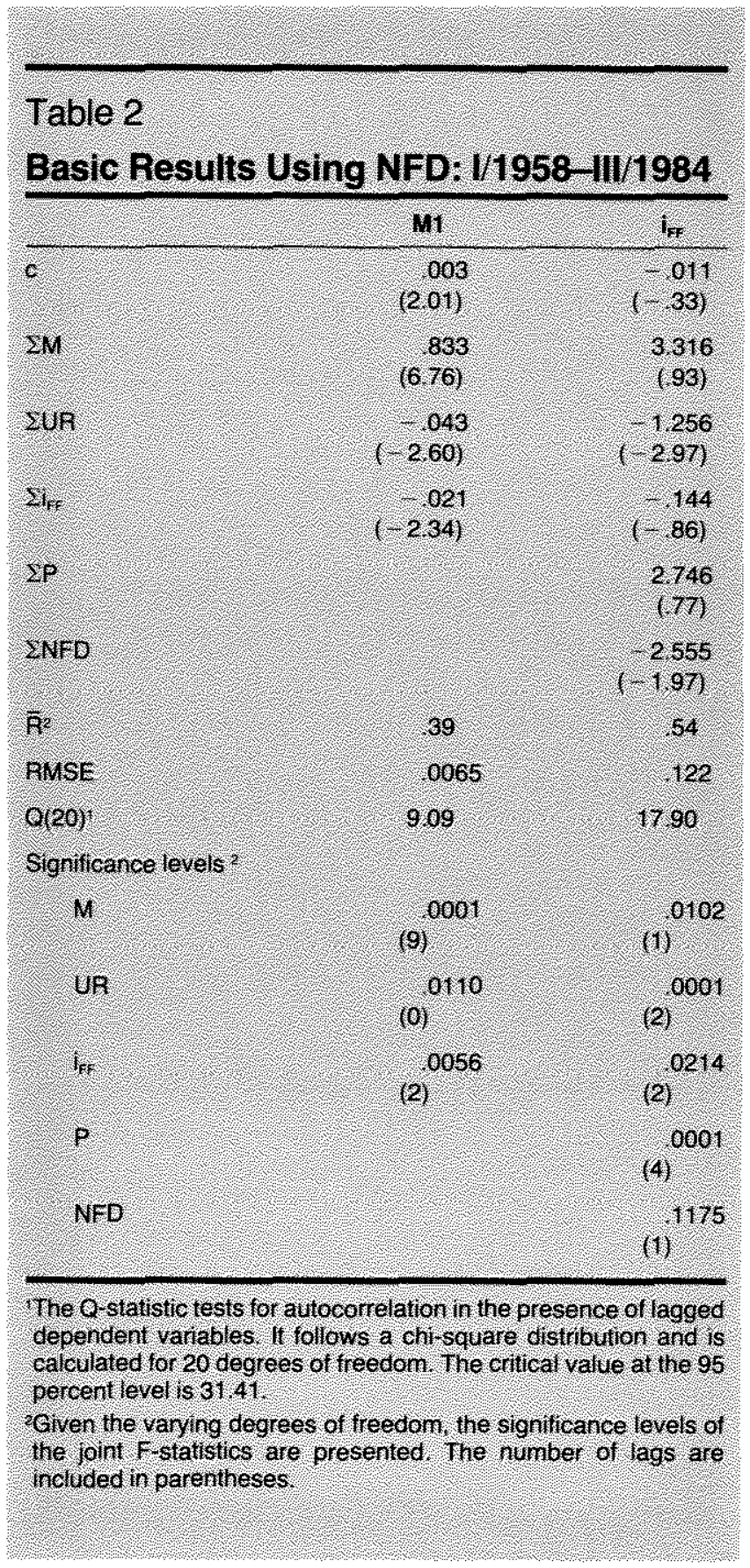

values are presented for the joint hypothesis that all the coefficients for a particular variable are equal to zero. These significance levels are presented since the lag lengths and corresponding degrees of freedom vary from one specification to another. The lag lengths are included in parentheses. Zero indicates that only the contemporaneous variable is included.

Since net federal debt, on average, had no significant impact on money during the 1958-84 period, it was omitted from the M1 equation. NFD is included in the 


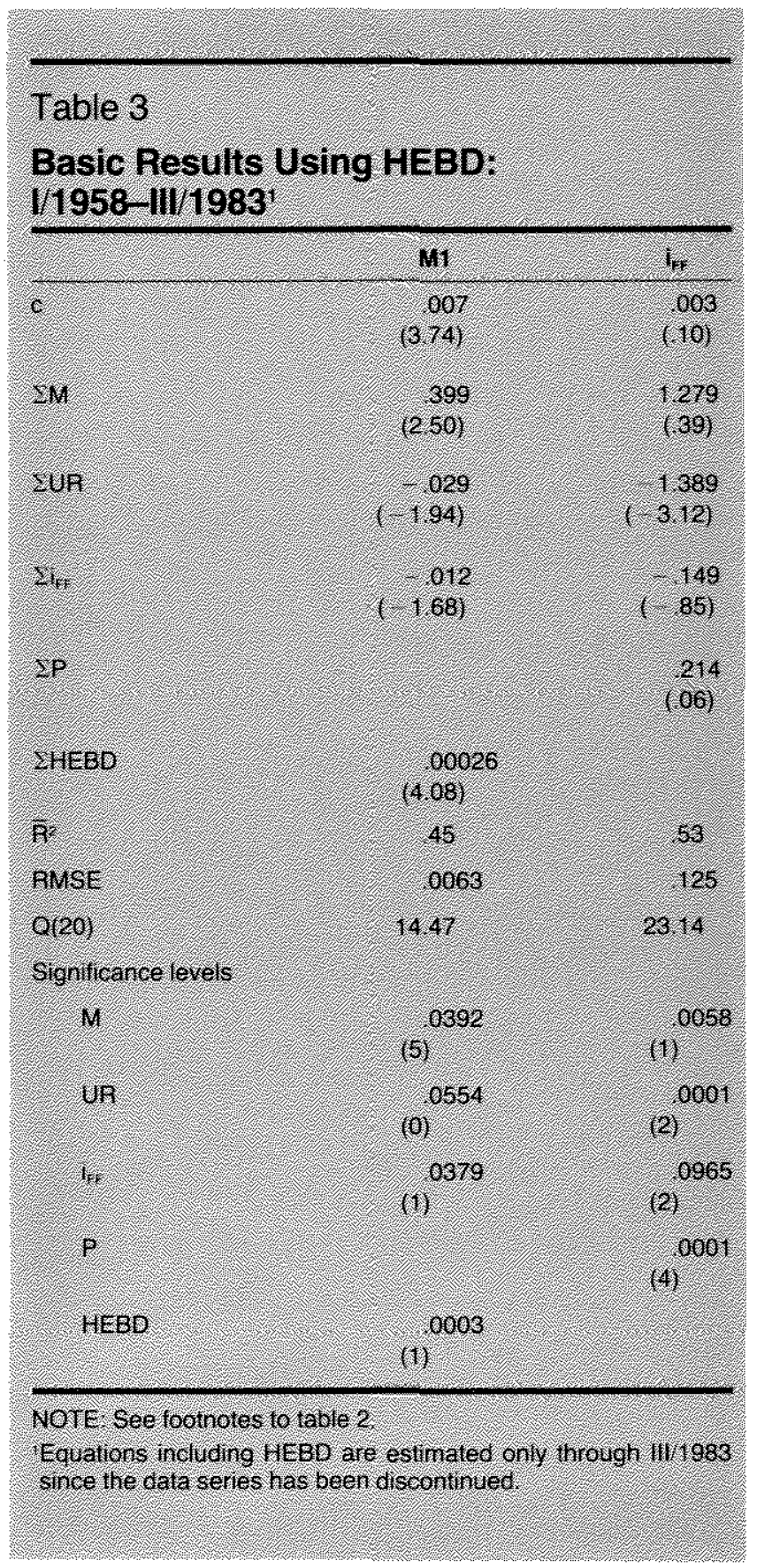

federal funds rate equation since the sum of its coefficients is significant at the 10 percent level. A 1 percent increase in NFD lowers the federal funds rate by an estimated 2.56 percent. Since NFD contains both structural and cyclical components, based on table 1 , it appears that the cyclical component of NFD dominates the structural component in the federal funds rate equation. Further, since NFD significantly enters the federal funds rate equation, the Federal Reserve apparently did not follow a pure interest rate strategy over the $1958-84$ period. This result is consistent with the hypothesized mixed targeting procedure."

The HEBD results presented in table 3 apparently yield conclusions at odds with these results. With the HEBD measure, the deficit has a significant positive impact on the money stock but no impact on the federal funds rate; consequently, it was omitted from the final estimated federal funds equation. Given HEBD as a measure of the structural deficit, the impact of HEBD on M1 and $i_{\mathrm{FF}}$ is consistent with the Federal Reserve, on average, pursuing an interest rate targeting strategy during the 1958-84 period.

The conditions presented in table 1 , however, represent only sufficient conditions for the structural deficit to have no impact on the federal funds rate. In other words, it is not necessary for the Federal Reserve to be targeting interest rates in order to generate the result that $H E B D$ does not influence $i_{F F}$. For example, if HEBD is small relative to the loanable funds market or if the supply of loanable funds is interest-elastic, then HEBD would have little influence on $i_{\mathrm{FF}}$ even with, say, a mixed largeting strategy.

Further, there is evidence to suggest that the structural deficit represents a relatively small fraction of the total demand for loanable funds. For example, in 1982, HEBD averaged $\$ 32.6$ billion while net credit market borrowing by nonfinancial sectors was $\$ 404.1$ billion. Thus, the HEBD component of federal borrowing was only 8.1 percent of funds borrowed. In contrast, on average from 1975 to 1981 , similar figures indicate HEBD was only 4.6 percent of net funds borrowed. HEBD may have little or no impact on interest rates not because of the particular targeting procedure used by the Federal Reserve, but rather because of the small relative size of the structural deficit. Given this interpretation, the results in table 3 are also consistent with a mixed targeting strategy.

\footnotetext{
${ }^{19}$ The coefficients on the non-debt terms in table 2 deserve comment. Inflation does not significantly enter the $\mathrm{M} 1$ equation and unemployment enters with a negative coefficient.
}

While the negative coefficient on the unemployment rate is significant in all equations, its economic impact is minor. For example, a reduction in the unemployment rate from 7.5 percent to 7.0 percent would increase the growth rate of money by only 0.2 percent. The procyclical response of monetary policy to the unemployment rate is certainly not intuitive; it is, however, consistent with the findings of Abrams, Froyen and Waud (1980).

Although the sum of the coefficients on the inflation term in the federal funds rate equation is not significant, the joint impact is significant. The short-run impacts are large in magnitude although approximately offsetting over a year. Similarly, the sum of the coefficients on money growth in the federal funds rate equation are not significantly different from zero. Again, it is the result of offsetting individual coefficients. 


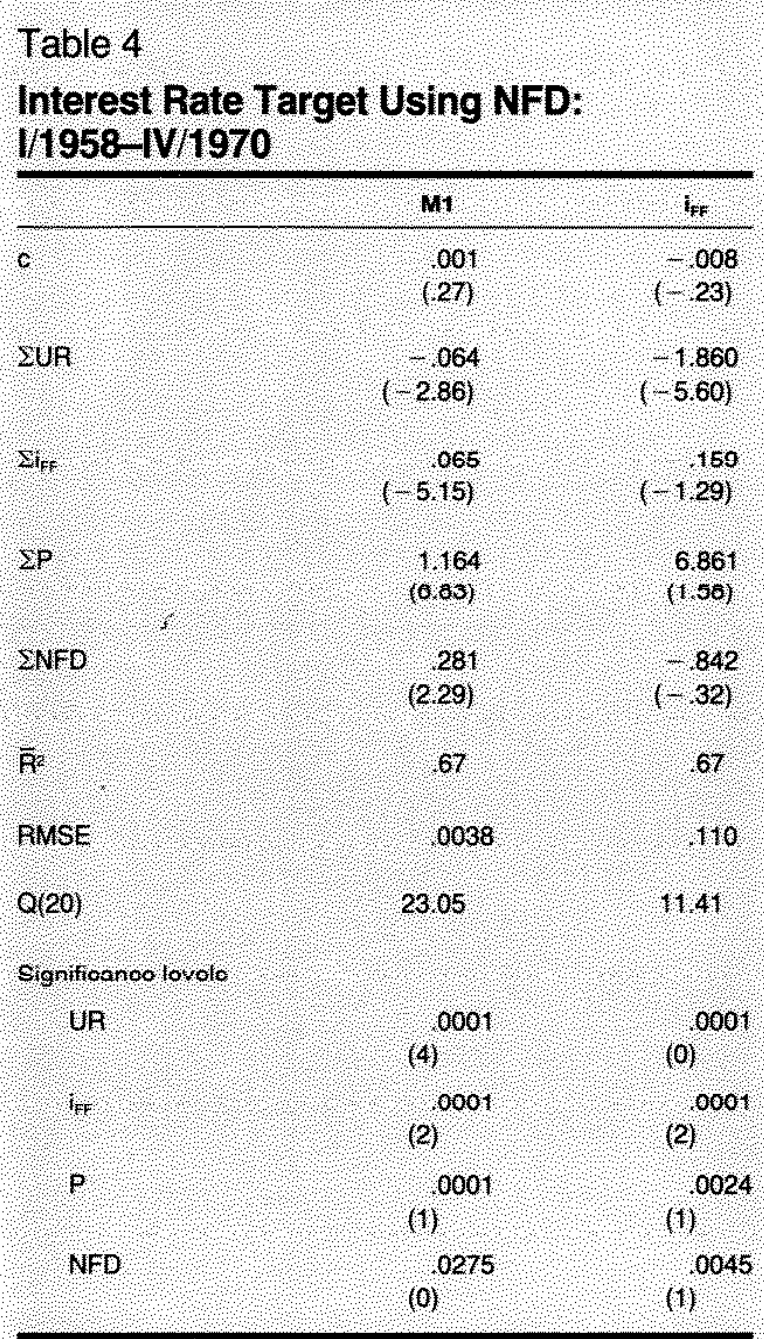

NOTE, See lootnotes to rable ?

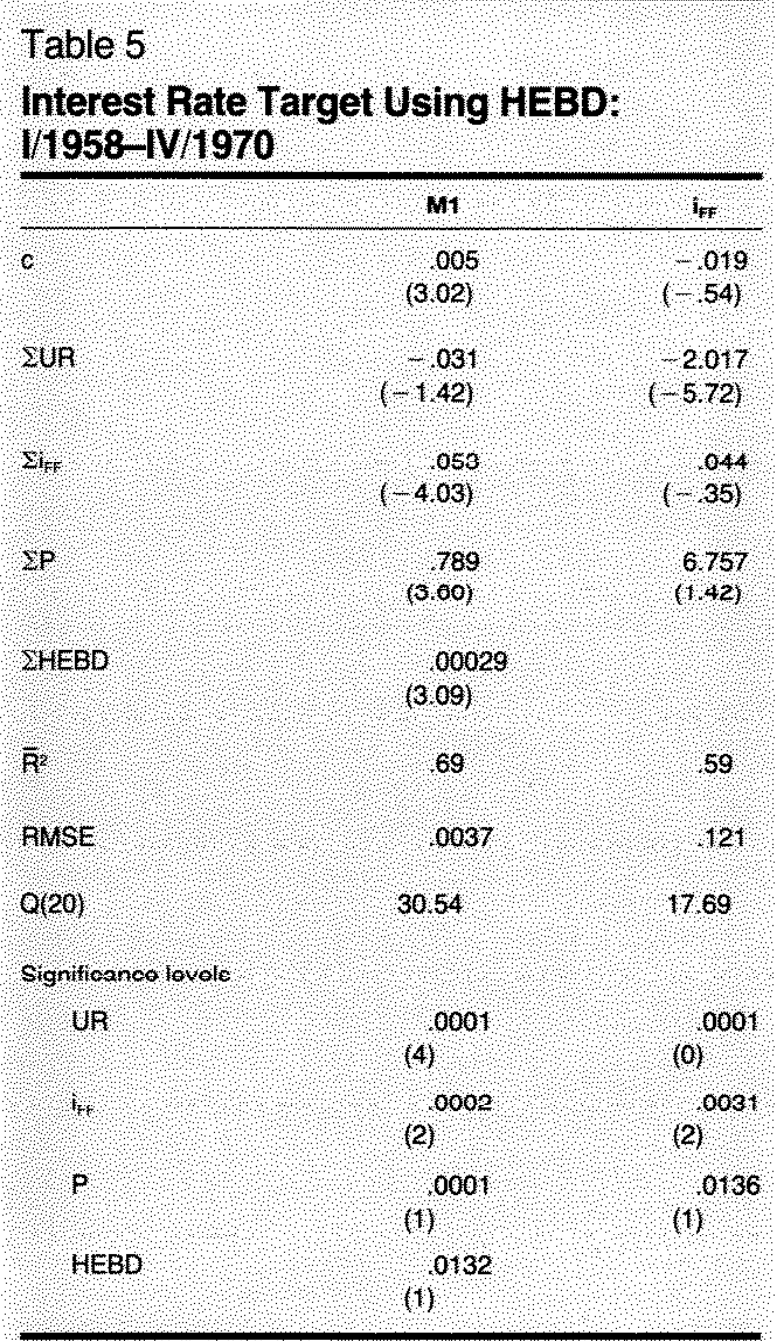

NOTE. See tootnotes to table 2 .

by lower interest rates this period, but that decline in the federal funds rate will be oflsel next period, witl the funds rate returning to its previous level. Thus, the NFD results are consistent with interest rate targeting, assuming a one-ruarter lag hefore the Ferteral Reserve. can effectively offset interest rate changes.

The HEBD results in table 5 generally are consistent with the NFD results. HEBD is significant in the money equation but insignificant in the federal funds rate equation. An increase in the structural deficit leads to an increase in the money siock during the early pertod but has no effect on the federal funds rate. This HEBD result is also consistent with interest rate targeting. The NFD and HEBD results differ only in their timing. NFD has a slightly faster impact on the money stock 


\section{Table 6}

\section{Mixed Targoting Procedure Using NFD:} 1/1971-III/1984

\begin{tabular}{|c|c|c|}
\hline & M1 & 1,1 \\
\hline c & $\begin{array}{r}020 \\
(4.69)\end{array}$ & $(-1.08 \%$ \\
\hline $2 \mathrm{M}$ & & $\begin{array}{l}8.246 \\
(1.20)\end{array}$ \\
\hline LUR & & $\begin{array}{l}-1.372 \\
(-3.011\end{array}$ \\
\hline$\Sigma_{l}$, & $(-, 77)$ & $(-2.06)$ \\
\hline $\mathrm{sP}$ & $(-1.65)$ & $\begin{array}{l}8.549 \\
1.591\end{array}$ \\
\hline$\angle N F D$ & $\begin{array}{l}087 \\
(1,4)\end{array}$ & $\begin{array}{r}3.613 \\
(-2.28)\end{array}$ \\
\hline q & 21 & 58 \\
\hline RMSE & 0072 & 111 \\
\hline$Q(20)$ & 9.81 & 1134 \\
\hline \multicolumn{3}{|c|}{ Gignificonco lovels } \\
\hline M & & $(6)$ \\
\hline Un & & $\left(1^{.0052}\right.$ \\
\hline Ir & $(1)^{0202}$ & (2) 0228 \\
\hline$P$ & (0) 1047 & $(3)^{0967}$ \\
\hline NFD & (0) 2616 & ${ }^{0882}$ \\
\hline
\end{tabular}

NOTE See footnotes to table 2

and a temporary effect on the federal funds rate. HEBD takes one quarter longer in reaching its full impact on money and has no effect on the federal funds rate."

Equations estimated only over the 1971-84 period, which corresponds to a period of greater reliance on a monctary aggregate target, аге presented in tables $G$ and 7 . The NFD and HEBD equations both imply that debt growth did not influence the money stock over this period. Again, when the federal funds rate equa-

20With respect to the non-debt terms, there are some interesting differencess hetween the early perind and the full neriod results, in particular for the money stock equation. The money stock continues to respond countercyclically to unemployment, but it also responds countercyclically to inflation in the early period. Also, lagged money terms are insignificant.

\section{Table 7}

Mixed Targeting Procedure Using HEBD: I/1971-III/1983

\begin{tabular}{|c|c|c|}
\hline & $\mathrm{ni}$ & $I_{f}$ \\
\hline c. & $(3.87)$ & $\left(\begin{array}{r}. \\
1,35)\end{array}\right.$ \\
\hline $\mathrm{zM}$ & & $\begin{array}{l}9.589 \\
(1.22)\end{array}$ \\
\hline YUR & & $(-1.562$ \\
\hline$\Sigma_{l, 7}$ & $(-.005)$ & $(-,-597$ \\
\hline $\mathrm{\Sigma P}$ & $(-1.17)$ & $\begin{array}{l}5.611 \\
(1.06)\end{array}$ \\
\hline ¿HEBD & $\begin{array}{l}.00014 \\
(1.64)\end{array}$ & \\
\hline $\bar{R}^{2}$ & 25 & 57 \\
\hline BMSE & 072 & 116 \\
\hline$Q(20)$ & 906 & 6.38 \\
\hline
\end{tabular}

Significance lovels

$\mathrm{M}$

(6)

un

$i_{\text {GF }}$

1)

P

2474

(0)

0663

HEBD

(0)

NOTE See footnotes to table 2

tion is estimated with NFD, that variable is significant; when it is estimated with HEBD, the deficit measure is insignificant. As in the discussion of the complete period results, the finding that $H E B D$ has not influenced the federal funds rate may be due more to the small size of the structural deficit vs. total credit demand than it is to the targeting procedures of the Federal Reserve. ${ }^{21}$ Thus, the later period estimation results are

21Even for the first three quarters of 1983, the last period for which HEBD is available, the structural deficit increases to only 10.4 percent of net credit market borrowing. Of course, the insignificance of HEBD conld also be a result of other causes. For axample helievers in currency substitution would argue that any increase in HEBD leading to increased real interest rates would also lead to foreign capital inflows that could drive interest rates back to approximately their original levels. 
consistent with the Federal Reserve following a monetary aggregate target .

The federal funds rate equations estimated over the later period were similar to those for the early and the full periods. In contrast, the money stock equations were substantially different in the later period. The money stock equations chosen by Akiake's FPE and $F$ tests consistently imply that virtually all variables entered, with the possible exception of the federal funds rate and the inflation rate, are insignificant.

From the perspective of estimating a reaction func tion that "explains" much of the variation in the money stock, the 1971-84 results leave much to be desired. They are, however, consistent with two very different theories of Federal Reserve behavior. First, it is possible that over this period the goals of the Federal Reserve or the weights on those goals were changing frequently, perhaps due to shifts in money demand, deregulation or financial innovations. If true, it would be impossible to estimate a consistent relationship between goals and the money stock. In the extreme, the money stock after detrending would be a random walk. Alternately, the Federal Reserve, on average, may have followed a constant money growth rate rule, In this case, the money stock after detrending would also be a random walk. Either of these hypotheses would be consistent with a poorly performing short-run reaction function for the money stock.

\section{SUMMARV ANO CONCLUSONS}

This paper has examined whether federal debt growth has influenced alternate measures of mone tary policy. It was demonstrated that a structural deficit would have very different implications than a cyclical deficit. A structural deficit in the static model presented here could lead to an increase in money growth and/or interest rates. In contrast, a cyclical deficit could be accompanied by a decrease in money growth and/or interest rates. Whether debt alters money growth or interest rates depends on the nature of the targeting strategy used by the Federal Reserve.

The results of a reaction function, developed and estimated over altemate intervals, suggest that prior to 1971 debt growth did lead to money growth but did not influence interest rates. Since then, debt growth has not altered money growth but may have been associated with interest rate changes. Net federal debt growth, which combines both structural and cyclical debt changes, is accompanied by a lower federal funds rate for the 1971-84 period. This result suggests that cyclical debt changes dominate structural in $\mathrm{NFD}^{r}$ effect on interest rates. In contrast, the high-employment budget deficit, a measure of structural debt changes only, has had no impact on the federal funds rate over any time period. This result may be due to HEBD's small size in comparison with total credit demands.

The results presented here are consistent with monetary policy being independent of federal deficits even though money market variables do apparently respond to those deficits. During the period when the Federal Reserve was targeting interest rates, the assumed policy measure, the federal funds fate, was unaffected by federal deficits. While the money stock does respond to deficits in the early time period, 1958 70, the money stock was not being used as a policy target in that interval. Conversely, in the later period, 1971-84, the Federal Reserve paid more attention to the money stock and less to interest rates. In that interval, the primary policy variable, the money stock, was again unaffected by federal deficits while those deficits may have had an impact on interest rates.

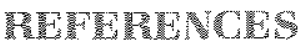

Abrams, Richard K., Richard Froyen and Roger N. Waud. "Monetary Policy Reaction Functions, Consistent Expectations, and The Burns Era," Journal of Money, Credit and Banking (February 1980), pp. $30-42$

Alen, Stuart D., and Michael D. Smith. "Government Borrowing and Monetary Accommodation," Journal of Monetary Economics (November 1983), pp. 605-16.

Barro, Robert J. "Unanticipated Money Growth and Unemployment in the United States, ${ }^{11}$ American Economic Review (March 1977), pp. 101-15.

Barth, James R., Robin Sickles and Philip Wiest. "Assessing the Impact of Varying Economic Conditions on Federal Reserve Behavior," Joumal of Macroeconomics (Winter 1982), pp. $47=70$

Batten, Dallas S., and Daniel L. Thornton. "How Robus: Are the Policy Conclusions of the St. Louis Equation?: Some Further Evidence," this Review (June/July 1984), pp. 26-32.

Darby, Michael R. "Some Pleasant Monetarist Arithmetic," Federal Reserve Bank of Minneapolis Quarterly Review (Spring 1984), pp. $15-20$.

deLeeuw, Frank, and Thomas M. Holloway. "The High-Employment Budget: Revised Estimates and Automatic Inflation Effects," Survey of Current Business (Aprit 1982), pp. 21-33.

DeRosa, Paul, and Gary H. Stern. "Monetary Control and the Fed" eral Funds Rate," Journal of Monetary Economics (April 1977), pp. $217-30$.

Dwyer, Gerald P., Jr. "Inflation and Govemment Deficits," Economic Inquiry (July 1982), pp. 315-29.

\footnotetext{
rOne hypothesis not tested here is that the Federal Reserve has shifted largets, say, from monetary aggregates to interest rates, in response to federal deficits. This change would represent another way in which debt growth could influence monetary policy.
} 
Eisner, Robert, and Paul J. Pieper. "A New View of the Federal Debt and Budget Deficits," American Economic Review (March 1984), pp. 11-29.

Froyen, Richard T. "A Test of the Endogeneity of Monetary Policy," Joumal of Econometrics (July 1974), pp. 175-88.

Hamburger, Michael $j_{.}$, and Burton Zwick. "Deficits, Money and Inflation," Journal of Monetary Economics (January 1981), pp. $141-50$.

"Deficits, Money and Inflation: Reply." Journal of Monetary Economics (September 1982), pp. $279-83$.

Havrilesky, Thomas, Robert H. Sapp and Robert L. Schweitzer. "Tests of the Federal Reserve's Reaction to the State of the Economy, "Social Science Quarterly (March 1975), pp. 835-52.

Hoffman, Dennis L., Stuart A. Low and Hubert H. Reineberg. "Re" cent Evidence on the Relationship between Money Growth and Budget Deficits, ${ }^{*}$ Journal of Macroeconomics (Spring 1983), pp. 223-31.

Levy, Mickey D. "Factors Affecting Monetary Policy in an Era of Inflation," Joumal of Monetary Economics (November 1981), pp. $351-73$.

Lombra, Raymond E., and Herbert M. Kautman. "The Money Supply Process: Identification, Stability, and Estimation," Southern Economic Journal (April 1984), pp. 1147-59.

Lombra, Raymond and Michael Moran. "Policy Advice and Policymaking at the Federal Reserve," in Kanl Brunner and Allan $H$ Meltzer, eds., Monetary Institutions and the Policy Process, Carnegie-Rochester Conterence Series on Public Policy (Autumn 1980), pp. $9-68$.

Makin, John H. "Real Interest, Money Surprises, Anticipated Infla" tion and Fiscal Deficits, Review of Economics and Statistics (August 1983), pp. 374-84.
McMillin, W. Douglas, and Thomas R. Beard. "Deficits, Money and Inflation: Comment," Journal of Monetary Economics (September 1982), pp. 273-77.

"The Impact of Fiscal Policy on the Money Supply in the U.S.: Theory and Empirical Evidence," Rivista Internazionale di Scienze Economiche e Commerciali (1981), pp. 941-57.

"The Short Run Impact of Fiscal Policy on the Money Supply," Southern Economic Joumal (July 1980), pp. 122-35.

Miller Preston J., and Thomas J. Sargent. "A Reply to Darby," Federal Reserve Bank of Minneapolis Quarterly Review (Spring 1984), pp. 2†-26.

Niskanen, William A. "Deficits, Government Spending, and Infla. tion: What is the Evidence?" Joumal of Monetary Economics (August 1978 ), pp. $591-602$.

Plosser, Charles I. "Government Financing Decisions and Asset Returns," Journal of Monetary Economics (May 1982), pp. 325-52.

Potts, Glenn T., and Dudley G. Luckett. "Policy Objectives of the Federal Reserve System," Quarterly Joumal of Economics (August 1978), pp. 525-34.

Sargent, Thomas J, and Neil Wallace. "Some Unpleasant Monetarist Arithmetic," Federal Reserve Bank of Minneapolis Quarterly Review (Fall 1981), pp. $1-17$.

Tatom, John A. "A Perspective on the Federal Deficit Problem," this Review (June/July 1984), pp. 5-17.

Thornton, Daniel L. "Monetizing the Debt," this Review (December 1984), pp. $30-43$.

. "The FOMC in 1982: De-Emphasizing $M 1$," this Review (June/July 1983), pp. 26-35.

Wallich, Henry C., and Peter M. Keir. "The Role of Operating Guides in U.S. Monetary Policy: A Historical Review," Federal Reserve Bulletin (September 1979), pp. 679-90. 